\title{
Catalysis

\section{Highly durable Pt-free fuel cell catalysts prepared by multi-step pyrolysis of Fe phthalocyanine and phenolic resin}

Cite this: Catal. Sci. Technol., 2014, 4,1400

Received 28th January 2014, Accepted 13th February 2014

DOI: $10.1039 / c 4 c y 00119 b$

www.rsc.org/catalysis

\author{
Yuta Nabae, ${ }^{* a}$ Mayu Sonoda, ${ }^{a}$ Chiharu Yamauchi, ${ }^{a}$ Yo Hosaka, ${ }^{a}$ Ayano Isoda ${ }^{b}$ \\ and Tsutomu Aoki ${ }^{\mathrm{b}}$
}

\begin{abstract}
Pt-free cathode catalysts for polymer electrolyte membrane fuel cells have been developed by multistep pyrolysis of Fe phthalocyanine (FePc) and phenolic resin (PhRs), the best of which shows a promising fuel cell performance: $1.0 \mathrm{~A} \mathrm{~cm}^{-2}$ at $0.38 \mathrm{~V}$ with $0.2 \mathrm{MPa}$ of $\mathrm{H}_{2}$ and $\mathrm{O}_{2}$ at $80{ }^{\circ} \mathrm{C}$. Durability tests over $800 \mathrm{~h}$ have been completed and they suggest good stability of the catalyst. This promising fuel cell performance and durability can be achieved because the multi-step pyrolysis of FePc and PhRs can overcome the trade-off between the heat treatment temperature and catalytic activity by combining the stepwise heat treatments and acid washing.
\end{abstract}

\section{Introduction}

Polymer electrolyte fuel cells (PEFCs) have received a great deal of attention in terms of their applications in transportation, portable devices and combined heat and power systems based on their high energy conversion efficiency and scalability. One major problem for PEFCs in commercial applications is the cost and scarcity of platinum, which has been thought to be essential for the cathode catalyst for oxygen reduction reaction (ORR). It is extremely important to develop preciousmetal-free cathode catalysts.

Since Jasinski discovered the catalytic property of Co phthalocyanine ${ }^{1}$ and Jahnke reported the heat treatment of Co TAA (Co dibenzotetraazaannulene), ${ }^{2}$ numerous attempts have been made to develop precious-metal-free cathode catalysts by pyrolyzing precursors containing transition metals (mainly $\mathrm{Fe}$ or $\mathrm{Co}$ ), a nitrogen source and a carbon source. ${ }^{3-15}$ Although some of these precious-metal-free cathode catalysts show quite promising fuel cell performances, ${ }^{9,14}$ their durability needs to be much improved if they are to be considered for commercial applications.

While the majority of this class of catalysts contain transition metal species (mainly Fe or Co), the role of this transition metal is still much debated. One convincing model for the active sites is the catalytic center based on metal-N coordination. ${ }^{3}$ However, it has been pointed out that this metal-N

\footnotetext{
${ }^{a}$ Department of Organic and Polymeric Materials, Tokyo Institute of Technology, 2-12-1 S8-26 Ookayama, Meguro-ku, Tokyo 152-8552, Japan.

E-mail: nabae.y.aa@m.titech.ac.jp; Fax:+81 35734 2433; Tel: +81 357342429

${ }^{b}$ Toshiba Fuel Cell Power Systems Corporation, 4-1, Ukishima-cho, Kawasaki-ku, Kawasaki-shi, Kanagawa 210-0862, Japan
}

coordination is no longer stable in the catalysts treated at high temperature (over $800{ }^{\circ} \mathrm{C}$ ) ${ }^{8,15}$ In contrast, several research groups have focused on the nature of nitrogencontaining carbon itself. ${ }^{16,17}$ Regardless of whether the actual catalytically active sites contain Fe species or not, we assume that sufficient nitrogen content is essential to obtain highly active carbon-based ORR catalysts, and that Fe species are important to enhance the growth of the carbon network, although we do not eliminate the possibility of catalysis by the transition metal species during the ORR.

Our research group has been developing precious-metal-free cathode catalysts based on pyrolysis of polymer precursors such as phenolic resin ${ }^{18-20}$ and nitrogen containing polymers. ${ }^{21}$ Our catalyst materials are prepared by pyrolyzing these mixtures rather than surface modification of ready-made carbon supports, such as carbon blacks. This approach could result in high density of active sites and high durability of the resulting catalysts, since the chemical structure of the active sites can be produced both in the bulk and on the surface of the carbon. In the catalyst preparation from such polymer based precursors, the pyrolysis protocol is quite important to obtain highly active and highly durable ORR catalysts.

This study focuses on how the durability of carbon-based ORR catalysts can be improved without losing catalytically active sites. We hereby report a multi-step pyrolysis of $\mathrm{Fe}$ phthalocyanine (FePc) and phenolic resin (PhRs) to prepare highly active and highly stable ORR catalysts, the concept of which is shown in Fig. 1. The hypothesis is based on the conclusion of our previous work: Fe species are important at up to $600{ }^{\circ} \mathrm{C}$ for the growth of the carbon network, but Fe nanoparticles kill the active sites at over $700{ }^{\circ} \mathrm{C} .{ }^{20}$ If one assumes that the chemical structure of the active sites has been 


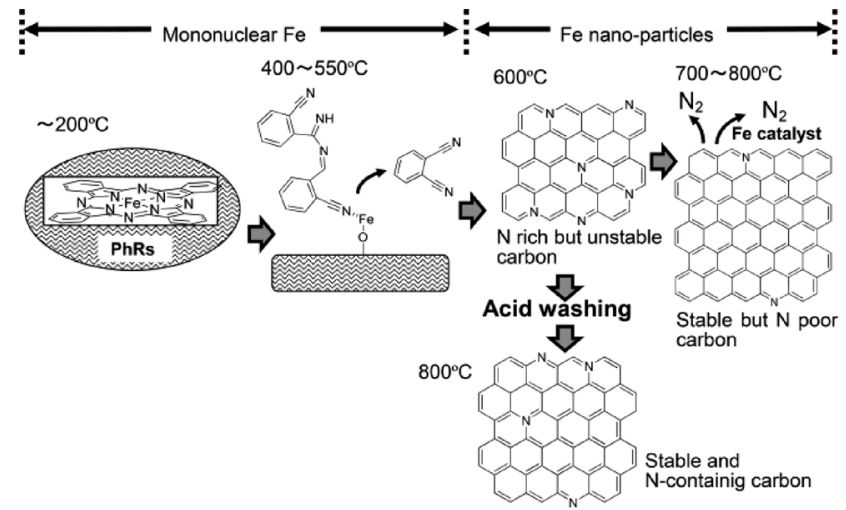

Fig. 1 The concept of multi-step pyrolysis.

formed at around $600{ }^{\circ} \mathrm{C}$, the post-treatment of the catalysts prepared at $600{ }^{\circ} \mathrm{C}$ could be effective to improve the stability after removing the Fe species that kill the active sites. The current paper describes the properties of the $\mathrm{FePc} / \mathrm{PhRs}$ derived cathode catalysts prepared by different pyrolysis protocols and the fuel cell performances using the prepared catalyst.

\section{Experimental}

\section{FePc/PhRs composite}

PhRs (Gunei Chemical, PSK-2320) was dissolved in acetone, and then FePc (Tokyo Kasei) was dispersed into the solution by ultra-sonication. The solvent was removed using a rotary evaporator to obtain powdery mixtures of the precursors. The amount of Fe was $2.3 \mathrm{wt} \%$.

\section{Carbonization protocols}

The composites were converted into carbon materials by multi-step pyrolysis. The pyrolysis yield was calculated from the weight difference before and after pyrolysis. 600-I- $\mathrm{N}_{2}-\mathrm{g}$ and $800-\mathrm{I}-\mathrm{N}_{2}-\mathrm{g}$ were prepared by single step pyrolysis of the $\mathrm{FePc} / \mathrm{PhRs}$ composite under nitrogen flow at 600 and $800{ }^{\circ} \mathrm{C}$, with pyrolysis yields of 49 and $49 \%$, respectively. These samples were mechanically ground using a planetary ball mill (Fritsch, P7) and $\mathrm{ZrO}_{2}$ beads (Nikkato, $0.5 \mathrm{~mm}$ ) in an EtOH and $\mathrm{H}_{2} \mathrm{O}$ solution. $800-\mathrm{II}-\mathrm{N}_{2}-\mathrm{g}$ and $800-\mathrm{II}-\mathrm{NH}_{3}-\mathrm{g}$ were prepared by pyrolyzing $600-\mathrm{I}-\mathrm{N}_{2}-\mathrm{g}$ at $800{ }^{\circ} \mathrm{C}$ under nitrogen and ammonia flows, with pyrolysis yields of 82 and $68 \%$, respectively. $1000-\mathrm{III}-\mathrm{NH}_{3}-\mathrm{g}$ was prepared by pyrolyzing $800-\mathrm{II}-\mathrm{NH}_{3}-\mathrm{g}$ at $1000{ }^{\circ} \mathrm{C}$ under ammonia flow with a pyrolysis yield of $44 \%$. Acid washing with $\mathrm{HCl}$ was carried out after each pyrolysis step in the following manner: a powder sample was stirred in conc. $\mathrm{HCl}$ for a few hours and then filtered. After repeating this once more, the powder was stirred in conc. $\mathrm{HCl}$ overnight. The resulting powder was carefully washed with ultrapure water. 1000-III- $\mathrm{NH}_{3}$-guw was prepared without the acid washing after the final pyrolysis step. 1000-III- $\mathrm{NH}_{3}$ was prepared without the ball milling process.

\section{Characterization}

The specific surface area and the mesopore volume of the catalysts were determined by $\mathrm{N}_{2}$ adsorption using a volumetric adsorption measurement instrument (Bel Japan, Belsorp-mini II). The BET surface area and the mesopore surface area were determined by the BET method and $\mathrm{BJH}$ method, respectively. The $\mathrm{C}, \mathrm{H}$ and $\mathrm{N}$ contents of the catalysts were determined using a CHN elemental analyzer (PerkinElmer, 2400-II). The Fe content was determined by wavelength dispersive spectrometry (WDS) using an electron probe micro analyzer (EPMA; JXA-8100, JEOL). Fe detection was conducted using a LiFH crystal. The EPMA measurement was carried out by analyzing a pellet prepared from the catalyst powder without any binder. X-ray photoelectron spectroscopy (XPS) was carried out using a spectrometer equipped (JPS-9010MC, JEOL) with a monochrometer and an $\mathrm{Al}$ anode at $12 \mathrm{kV}$ and $25 \mathrm{~mA}$. The binding energy was charge corrected with respect to the $\mathrm{C} 1 \mathrm{~s}$ signal at $284.6 \mathrm{eV}$ derived from aromatic carbon. ${ }^{22} \mathrm{X}$-ray diffraction (XRD) was carried out at room temperature using an X-ray diffractometer (Rigaku, Ultima IV) with $\mathrm{Cu} \mathrm{K} \alpha$ radiation. Scanning electron microscopy (SEM) and transition electron microscopy (TEM) were carried out using a VE9800 spectrometer (Keyence) and a $200 \mathrm{kV}$ FE-TEM (2010F, JEOL), respectively.

\section{Half cell testing}

The catalytic activity of the samples was evaluated by linear sweep voltammetry (LSV, $5 \mathrm{mV} \mathrm{s}^{-1}$ ) with a rotating disk electrode (RDE). The catalyst powder was dispersed in a mixture of Nafion solution ( $5 \mathrm{wt} \%$, Aldrich), ethanol and water and applied onto the surface of a glassy carbon electrode. The amount of loaded catalyst was $0.2 \mathrm{mg} \mathrm{cm}^{-2}$. The rotation speed of the RDE was kept at $1500 \mathrm{rpm}$ using a RDE system (Nikko Keisoku, RDE-1) and the electrochemical data were collected using a potentiostat (ALS, 2323). The LSV was first carried out in $\mathrm{N}_{2}$ saturated $\mathrm{H}_{2} \mathrm{SO}_{4}(0.5 \mathrm{M})$, and then in $\mathrm{O}_{2}$ saturated $\mathrm{H}_{2} \mathrm{SO}_{4}$. The ORR current was determined by subtracting the $\mathrm{N}_{2}$ current from the $\mathrm{O}_{2}$ current.

\section{Fuel cell testing}

A cathode was fabricated by applying an ink of the $1000-\mathrm{III}-\mathrm{NH}_{3}-\mathrm{g}$ catalyst and the Nafion binder (du Pont 20 wt\% DE2021CS) onto a gas diffusion layer (SGL, GDL25BC) using an Auto Film Applicator (Tester Sangyo). An anode was fabricated using a PtRu/Ketjen black catalyst (Tanaka, TEC61E54) in the same manner. An MEA (Membrane Electrode Assembly) was fabricated by pressing the electrodes and the Nafion NR211 membrane (du Pont) at $150{ }^{\circ} \mathrm{C}$ and $30 \mathrm{~kg} \mathrm{~cm}^{-2}$ for $2 \mathrm{~min}$.

The MEA performance was tested at $80{ }^{\circ} \mathrm{C}$ by flowing fully humidified hydrogen $\left(300 \mathrm{~mL} \mathrm{~min}^{-1}\right)$ into the anode side and fully humidified oxygen or air into the cathode side $\left(300 \mathrm{~mL} \mathrm{~min}^{-1}\right)$. The absolute pressures of the anode and cathode compartments were maintained at $0.2 \mathrm{MPa}$. $I-V$ polarization curves were measured by recording the cell voltages after holding the current density using an Electronic Load (Kikusui, PLZ164WA) for $5 \mathrm{~min}$ at each value. Durability tests were carried out by holding the current density at $200 \mathrm{~mA} \mathrm{~cm}^{-2}$ and recording the cell voltage. 


\section{Results and discussion}

Different protocols for catalyst preparation

Table 1 summarizes the elemental compositions and specific surface areas of the catalysts prepared by different pyrolysis protocols. $800-\mathrm{I}-\mathrm{N}_{2}-\mathrm{g}$ resulted in quite poor nitrogen content. This is because the single step pyrolysis at such a high temperature induces the $\mathrm{N}_{2}$ elimination catalysed by the Fe particles, as explained in Fig. 1. Higher nitrogen contents of $800-\mathrm{II}_{-} \mathrm{N}_{2}-\mathrm{g}$ and $800-\mathrm{II}-\mathrm{NH}_{3}-\mathrm{g}$ indicate that the acid washing before the treatment at $800{ }^{\circ} \mathrm{C}$ contributes to the retention of higher nitrogen contents. These data also suggest the contribution of the $\mathrm{NH}_{3}$ atmosphere for the higher nitrogen contents. It should be noted that $1000-\mathrm{III}-\mathrm{NH}_{3}$-g contains $1.9 \mathrm{wt} \%$ of nitrogen even after the treatment at $1000{ }^{\circ} \mathrm{C}$. As for the Fe content, 0.5-1.6 wt $\%$ of Fe species were detected from all of the samples despite the acid washing. $1.6 \mathrm{wt} \%$ of $\mathrm{Fe}$ content of $1000-\mathrm{III}-\mathrm{NH}_{3}-\mathrm{g}$ is certainly lower than $2.3 \mathrm{wt} \%$ of 1000 -III- $\mathrm{NH}_{3}$-guw, suggesting that the acid washing indeed decreases the Fe content but there are some unwashable Fe species in the sample. Another effect of the ammonia treatment is the etching of the carbon materials. ${ }^{12}$ The BET surface area $\left(A_{\mathrm{BET}}\right)$ and the mesopore surface area $\left(A_{\text {meso }}\right)$ of $800-\mathrm{II}-\mathrm{NH}_{3}-\mathrm{g}$ are higher than that of $800-\mathrm{II}-\mathrm{N}_{2}-\mathrm{g}$. The etching effect is more significant with $1000-\mathrm{III}-\mathrm{NH}_{3}$-g, especially for $A_{\text {meso, }}$ which is thought to be important for mass transport in the catalyst layers of fuel cells. The acid washing does not seem to affect the nitrogen content or the specific surface area, as observed in the $1000-\mathrm{III}-\mathrm{NH}_{3}$-g and 1000-III- $\mathrm{NH}_{3}$-guw samples.

Fig. 2 shows the XRD patterns of the catalysts prepared by different pyrolysis protocols. $600-\mathrm{I}-\mathrm{N}_{2}-\mathrm{g}$ shows small diffraction peaks due to metallic $\mathrm{Fe}$ and $\mathrm{Fe}_{3} \mathrm{C}$. This suggests that the phthalocyanine structure has started decomposing at around this temperature. The degree of graphitization is probably one of the most important properties to achieve the high stability of the carbon based cathode catalysts. In the $600-\mathrm{I}-\mathrm{N}_{2}$ and $800-\mathrm{II}-\mathrm{N}_{2}$-g samples, broad diffraction peaks spreading over $15-30^{\circ}$ due to amorphous carbon were observed. In contrast, the 1000-III- $\mathrm{NH}_{3}-\mathrm{g}$ sample shows a relatively sharp peak at $25.8^{\circ}$ due to turbostratic carbon. ${ }^{23}$

Fig. 3 shows the XPS spectra of the catalysts prepared by different pyrolysis protocols. The $\mathrm{C} 1 \mathrm{~s}$ spectrum of $600-\mathrm{I}-\mathrm{N}_{2}-\mathrm{g}$ can be deconvoluted into four peaks: aromatic carbon at $284.6 \mathrm{eV}$, ether $\left(\mathrm{C}^{*} \mathrm{OC}\right)$ species at $285.5 \mathrm{eV}$, ester $\left(\mathrm{C}^{*} \mathrm{OC}=\mathrm{O}\right)$

Table 1 Elemental compositions and specific surface areas of the catalysts prepared by different pyrolysis protocols

\begin{tabular}{|c|c|c|c|c|c|c|}
\hline \multirow[b]{2}{*}{ Sample name } & \multicolumn{3}{|c|}{$\begin{array}{l}\text { Elemental } \\
\text { analysis (wt\%) }\end{array}$} & \multirow{2}{*}{$\begin{array}{l}\text { EPMA } \\
\text { Fe (wt\%) }\end{array}$} & \multicolumn{2}{|c|}{$\begin{array}{l}\text { Specific surface } \\
\text { area }\left(\mathrm{m}^{2} \mathrm{~g}^{-1}\right)\end{array}$} \\
\hline & $\mathrm{C}$ & $\mathrm{H}$ & $\mathrm{N}$ & & $A_{\mathrm{BET}}$ & $A_{\text {meso }}$ \\
\hline $600-\mathrm{I}-\mathrm{N}_{2}-\mathrm{g}$ & 74.9 & 1.3 & 3.1 & 1.4 & 517 & 9 \\
\hline $800-\mathrm{I}-\mathrm{N}_{2}-\mathrm{g}$ & 92.1 & Trace & 0.7 & 0.5 & 484 & 284 \\
\hline $800-\mathrm{II}-\mathrm{N}_{2}-\mathrm{g}$ & 87.0 & 0.1 & 2.6 & 1.2 & 488 & 80 \\
\hline $800-\mathrm{II}-\mathrm{NH}_{3}-\mathrm{g}$ & 78.7 & 1.3 & 4.7 & 0.8 & 655 & 110 \\
\hline $1000-\mathrm{III}-\mathrm{NH}_{3}-\mathrm{g}$ & 84.3 & 0.8 & 1.9 & 1.6 & 918 & 220 \\
\hline $1000-\mathrm{III}-\mathrm{NH}_{3}$-guw & 77.5 & 1.8 & 2.0 & 2.3 & 860 & 219 \\
\hline $1000-\mathrm{III}-\mathrm{NH}_{3}$ & 84.7 & 0.2 & 1.4 & 1.0 & 739 & 166 \\
\hline
\end{tabular}

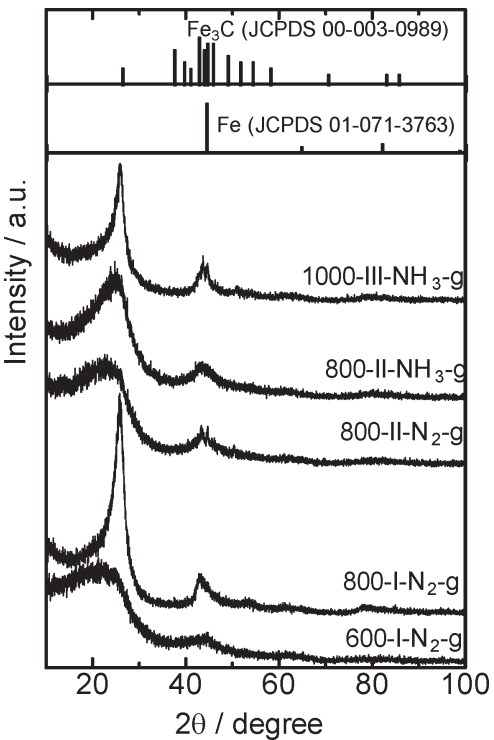

Fig. 2 XRD patterns of the catalysts prepared by different pyrolysis protocols.
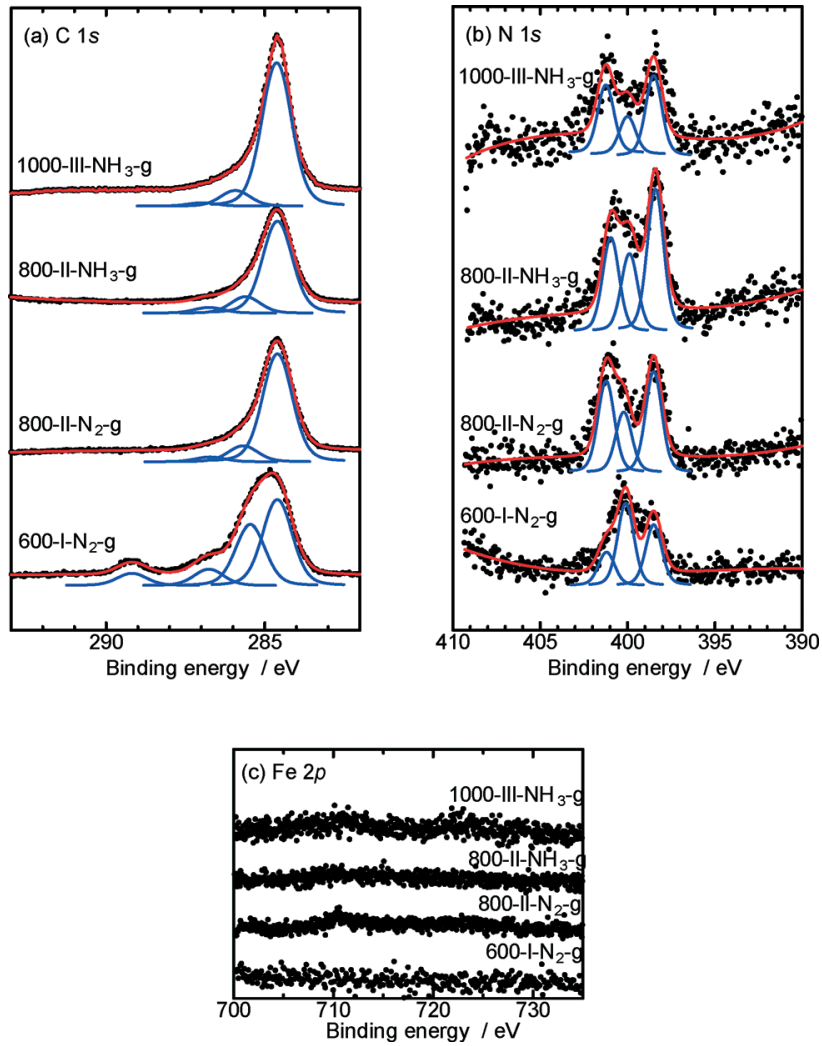

Fig. 3 (a) $\mathrm{C} 1 \mathrm{~s}$, (b) $\mathrm{N}$ 1s and (c) Fe 2p XPS spectra of the prepared carbon materials, dots: measured data; lines: fitted curves.

species at $286.8 \mathrm{eV}$ and carboxyl $\left(\mathrm{C}^{*}(=\mathrm{O}) \mathrm{O}\right)$ species at $289.2 \mathrm{eV}^{22}$ Three other samples prepared by the multi-step pyrolysis show more aromatic carbon, suggesting a well grown carbon network as evidenced by XRD patterns (Fig. 2). The $\mathbf{N}$ 1s spectra can be deconvoluted into three peaks: pyridinic (398.4-398.5 eV), pyrrolic (399.9-400.0 eV) and 
graphitic (401.0-401.2 eV). ${ }^{24}$ Apart from 600-I-N ${ }_{2}-\mathrm{g}$, the majority of $\mathrm{N} 1 \mathrm{~s}$ signals can be assigned to pyridinic and graphitic nitrogens which have been proposed as catalytically active nitrogen species. ${ }^{14,25}$ The Fe 2 p spectra were also measured under similar scanning conditions but only trace signals can be detected, suggesting that the concentration of Fe species on the catalyst surface is extremely low, whereas the bulk analysis (EPMA and XRD) detected considerable intensity of Fe signals. Our previous work suggests that the majority of FePc have decomposed and formed Fe nanoparticles at around $600{ }^{\circ} \mathrm{C} .{ }^{20}$ The residual $\mathrm{Fe}$ in the prepared carbon is probably in the form of nanoparticles fully encapsulated by carbon layers, and therefore can be detected by the bulk analysis whereas the acid washing removes most of the Fe species on the catalyst surface. This assumption is evidenced by TEM as shown in Fig. 4. The 1000-III- $\mathrm{NH}_{3}$ sample shows Fe particles covered by layered carbon even after the acid washing.

The EPMA, XRD, XPS and TEM analyses suggest that the majority of Fe species observed in the 1000-III- $\mathrm{NH}_{3}-\mathrm{g}$ sample are in metallic $\mathrm{Fe}$ or $\mathrm{Fe}_{3} \mathrm{C}$ form and the concentration of $\mathrm{Fe}$ species on the catalyst surface is extremely low. These Fe particles presumably catalyze the formation of the layered structure. $^{26}$ Note that $800-\mathrm{I}-\mathrm{N}_{2}-\mathrm{g}$ resulted in lower nitrogen content with a higher degree of graphitization. This is because the high temperature treatment with too much Fe species enhances the growth of carbon and the elimination of nitrogen species. These results suggest that controlling the catalysis of the Fe species is quite important to raise the heat treatment temperature without losing nitrogen species.

Fig. 5 shows the RDE voltammograms of the catalysts from various pyrolysis protocols. $800-\mathrm{I}-\mathrm{N}_{2}-\mathrm{g}$ shows quite poor ORR activity reflecting poor nitrogen content. The samples from the multi-step pyrolysis, 800-II- $\mathrm{N}_{2}-\mathrm{g}, 800-\mathrm{II}-\mathrm{NH}_{3}-\mathrm{g}$ and 1000-III- $\mathrm{NH}_{3}-\mathrm{g}$ show good catalytic activities even after the high-temperature treatment. This is probably because the multi-step pyrolysis can minimize the loss of nitrogen species since extraordinary Fe species has been washed out. 800-III- $\mathrm{NH}_{3}$-g shows even higher nitrogen content than $600-\mathrm{I}-\mathrm{N}_{2}-\mathrm{g}$ and a good ORR current. The nitrogen content of $1000-\mathrm{III}-\mathrm{NH}_{3}-\mathrm{g}$ is

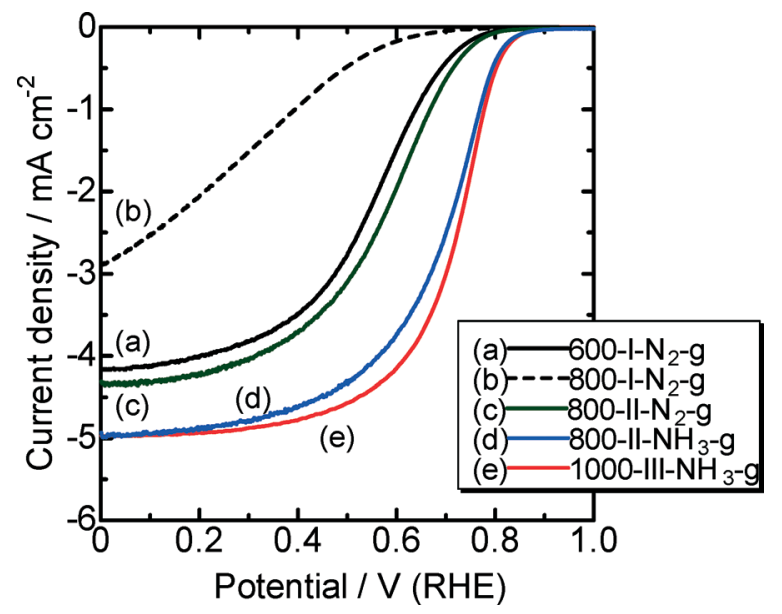

Fig. 5 ORR voltammograms of the catalysts prepared by various pyrolysis protocols. Temperature: RT, catalyst loading: $0.2 \mathrm{mg} \mathrm{cm}^{-2}$, electrolyte: $0.5 \mathrm{M} \mathrm{H}_{2} \mathrm{SO}_{4}$, rotation: $1500 \mathrm{rpm}$.

lower than that of $800-\mathrm{II}-\mathrm{NH}_{3}$ but also shows a quite good catalytic performance. This is probably because this sample has a high surface area due to the etching effect by $\mathrm{NH}_{3}$.

One might wonder if the different catalytic performances derive from the difference in the nature of Fe species among the samples. Fig. 6 compares the ORR voltammograms of 1000-III- $\mathrm{NH}_{3}$-g and 1000-III-NH $\mathrm{N}_{3}$-guw. Indeed, the ORR activity slightly decreases by the acid washing, and $1000-\mathrm{III}_{-} \mathrm{NH}_{3}-\mathrm{g}$ is still much active as a precious-metal-free catalyst. We do not eliminate the possibility of catalysis by Fe species during the ORR; however, the catalysts after the acid washing contain very little amount of Fe species on the surfaces (see Fig. 3) and it is quite difficult to discuss the correlation between the amount of $\mathrm{Fe}$ species and the catalytic activity. We assume that the different catalytic activities by different pyrolysis protocols mainly derive from the different nitrogen contents and specific surface areas.

\section{Effect of mechanical grinding}

Although the 1000-III- $\mathrm{NH}_{3}$ sample has relatively high surface area due to the porous structure introduced by the $\mathrm{NH}_{3}$

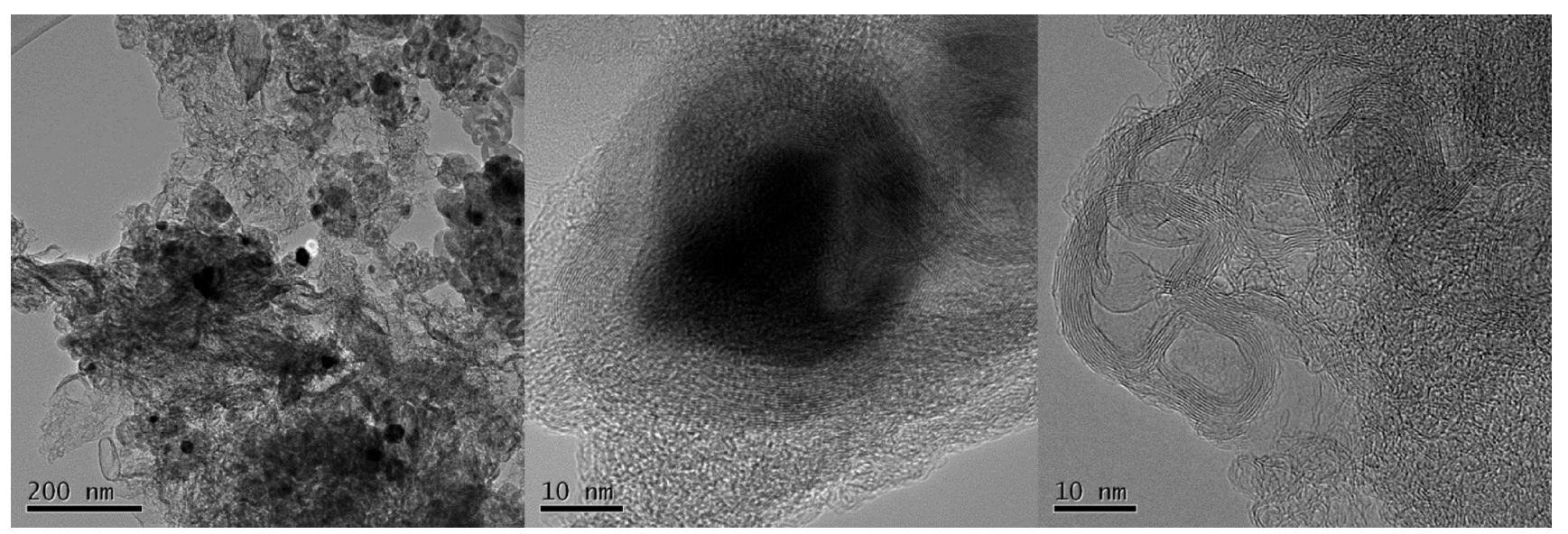

Fig. 4 TEM images of $1000-\mathrm{III}-\mathrm{NH}_{3}-\mathrm{g}$. 


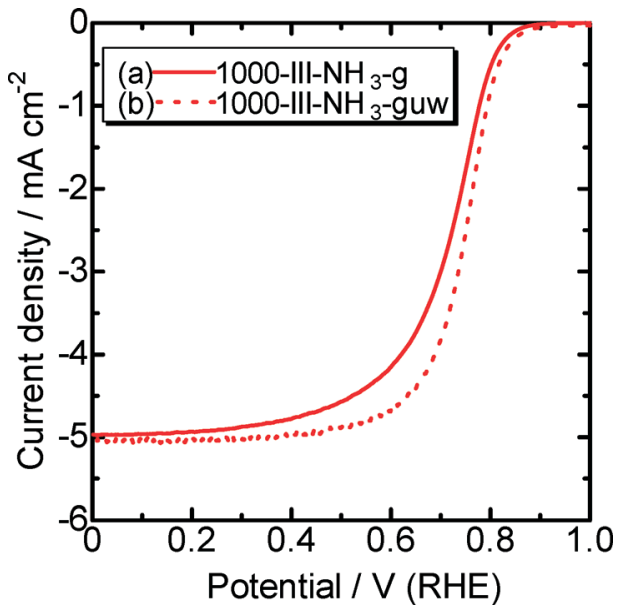

Fig. 6 ORR voltammograms of the $1000-$ III- $\mathrm{NH}_{3}-\mathrm{g}$ and $1000-\mathrm{III}-\mathrm{NH}_{3}$-guw catalysts. Temperature: RT, catalyst loading: $0.2 \mathrm{mg} \mathrm{cm}^{-2}$, electrolyte: $0.5 \mathrm{M} \mathrm{H}_{2} \mathrm{SO}_{4}$, rotation: $1500 \mathrm{rpm}$.

etching, the particle size of carbon might be an important parameter to achieve a high performance in fuel cells because the catalyst should be well mixed with the ionomer in the catalyst layer. In this context, the effect of mechanical ball milling was investigated. Fig. 7 shows the SEM images of the prepared catalyst with/without mechanical ball milling. The 1000-III- $\mathrm{NH}_{3}$ sample shows quite bulky structures of carbon around the $1 \mu \mathrm{m}$ scale. In contrast, the ball milled sample (1000-III- $\mathrm{NH}_{3}-\mathrm{g}$ ) shows a finer structure which is less than $300 \mathrm{~nm}$. In the meantime, the nitrogen content and BET surface area are slightly higher in $1000-\mathrm{III}-\mathrm{NH}_{3}$-g. This is because $1000-\mathrm{III}-\mathrm{NH}_{3}$-g was activated by $\mathrm{NH}_{3}$ more than $1000-\mathrm{NH}_{3}$ because it was mechanically ground before the $\mathrm{NH}_{3}$ treatment.

Fig. 8 shows the RDE voltammograms of the $1000-\mathrm{III}_{-} \mathrm{NH}_{3}$ and $1000-\mathrm{III}-\mathrm{NH}_{3}$-g samples. Reflecting the fine morphology, the ball milled sample (1000-III- $\mathrm{NH}_{3}-\mathrm{g}$ ) shows higher current density. This higher catalytic performance is probably due to an increased three phase boundary by the fine particle size or the increased BET surface area and nitrogen content. It is concluded that mechanical grinding on the pyrolysis protocol is effective to improve the catalytic performance of the prepared carbon.

\section{Fuel cell performance}

Since the 1000-III- $\mathrm{NH}_{3}$-g sample showed the best ORR current in the RDE voltammetry, this catalyst was tested in a real fuel cell. Fig. 9 shows the $I-V$ performance curve of the MEA prepared using the 1000-III- $\mathrm{NH}_{3}$-g sample as the cathode catalyst. The open circuit voltage was approximately $0.86 \mathrm{~V}$ and the current density reached $1.0 \mathrm{~A}$ at $0.38 \mathrm{~V}$. The performance in air for the cathode side is lower than that in $\mathrm{O}_{2}$; however, this also seems a promising performance. These fuel cell performances are much better than that of a previously reported study using similar precursors, ${ }^{27}$ suggesting that the multi-step pyrolysis is a quite effective protocol to convert the polymer based precursors into ORR active catalysts in the presence of Fe and nitrogen sources.
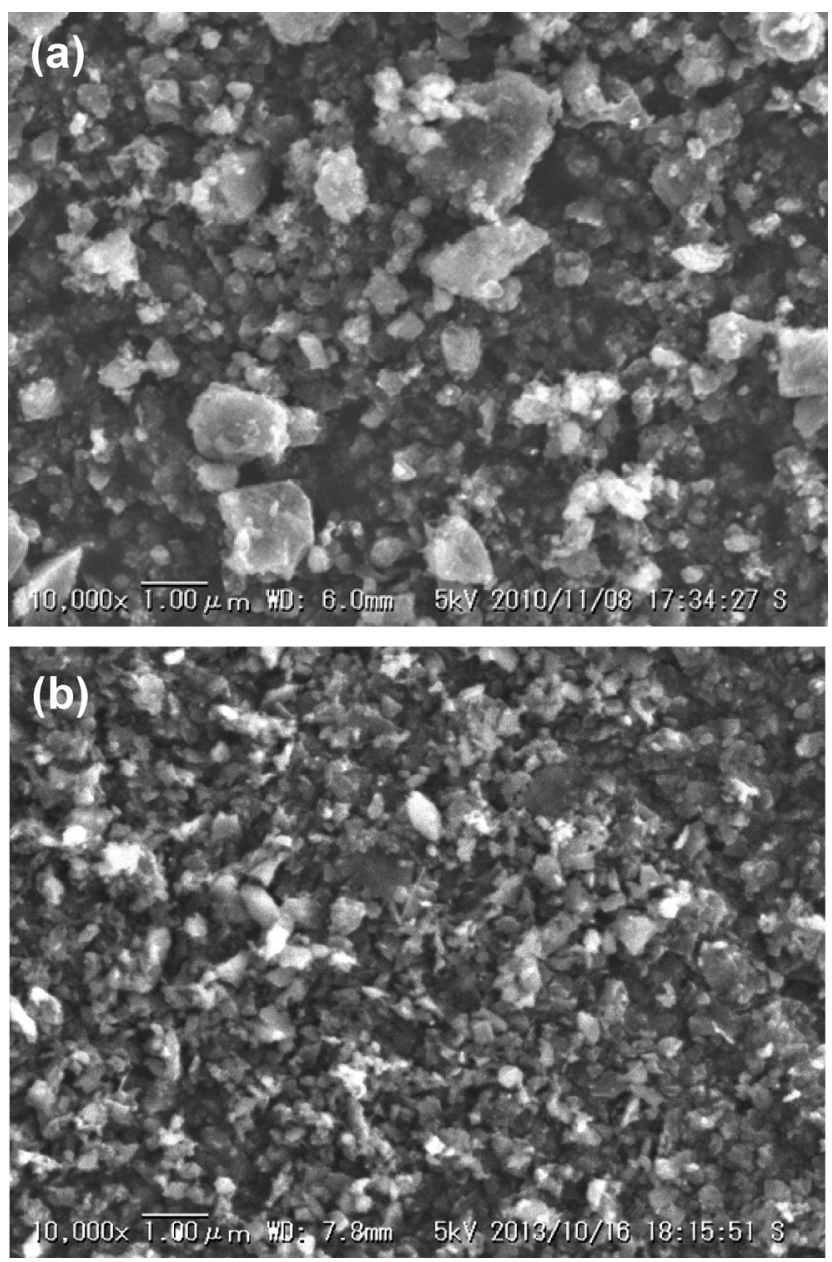

Fig. 7 SEM images of (a) $1000-\mathrm{III}-\mathrm{NH}_{3}$ and (b) $1000-\mathrm{III}-\mathrm{NH}_{3}-\mathrm{g}$.

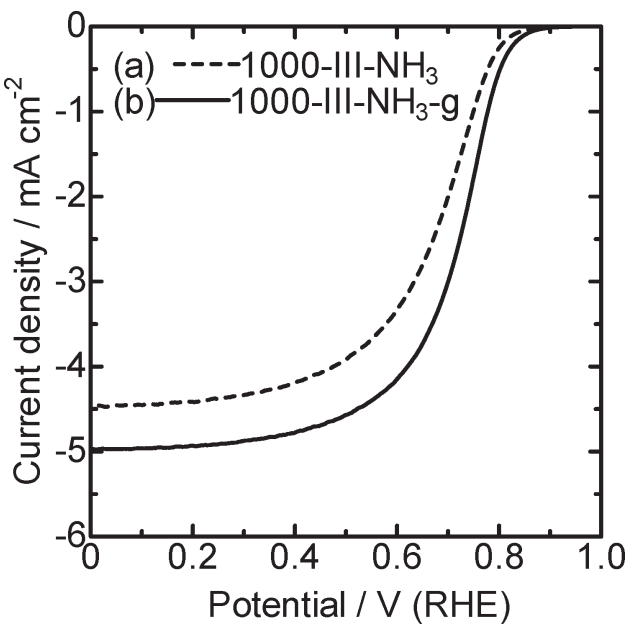

Fig. 8 ORR voltammograms of the $1000-\mathrm{III}-\mathrm{NH}_{3}$ and $1000-\mathrm{III}-\mathrm{NH}_{3}-\mathrm{g}$ catalysts. Temperature: RT, catalyst loading: $0.2 \mathrm{mg} \mathrm{cm}^{-2}$, electrolyte: $0.5 \mathrm{M} \mathrm{H}_{2} \mathrm{SO}_{4}$, rotation: $1500 \mathrm{rpm}$.

The durability tests of these fuel cells were carried out by introducing air into the cathode compartment and keeping the current density at $200 \mathrm{~mA} \mathrm{~cm}{ }^{-2}$ (Fig. 10). Although the cell voltage gradually decreases, the performance loss after $500 \mathrm{~h}$ 


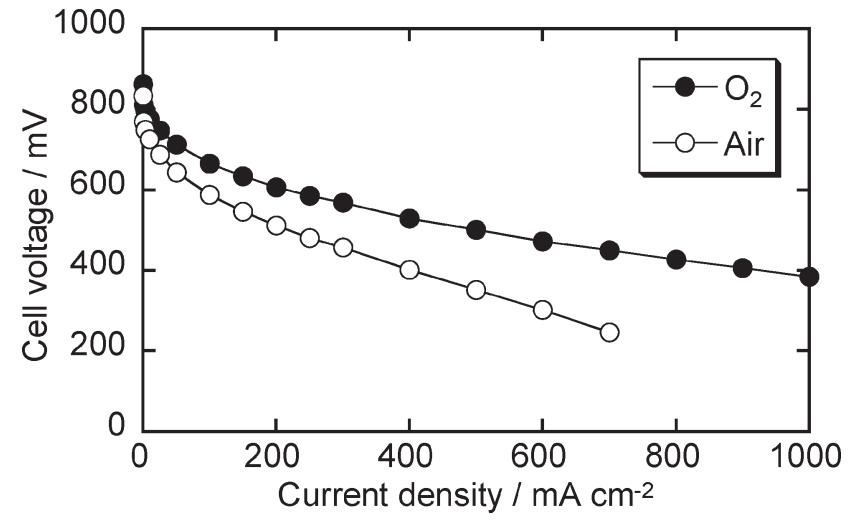

Fig. 9 I-V polarization curve of the MEA using the $1000-\mathrm{III}-\mathrm{NH}_{3}-\mathrm{g}$ catalyst. Cathode: $1000-\mathrm{III}-\mathrm{NH}_{3}-\mathrm{g}\left(4 \mathrm{mg} \mathrm{cm}^{-2}\right), \mathrm{O}_{2}(0.2 \mathrm{MPa})$. Anode: $\mathrm{PtRu} / \mathrm{C}$ catalyst $\left(0.4 \mathrm{mg}-\mathrm{Pt} \mathrm{\textrm {cm } ^ { - 2 }}\right), \mathrm{H}_{2}(0.2 \mathrm{MPa})$. Electrolyte: Nafion NR211. $T: 80^{\circ} \mathrm{C}$.

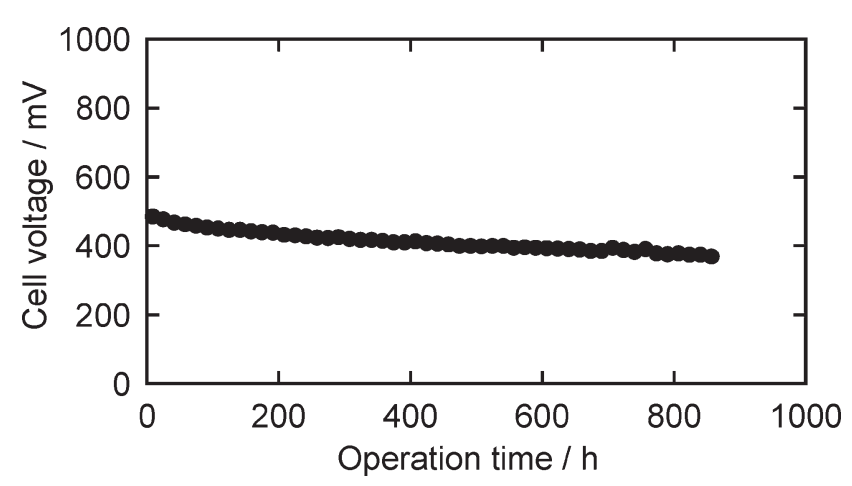

Fig. 10 Durability test of the MEA using the 1000-III- $\mathrm{NH}_{3}-\mathrm{g}$ catalyst. Cathode: air (0.2 MPa). Anode: $\mathrm{H}_{2}(0.2 \mathrm{MPa})$. Current density: $200 \mathrm{~mA} \mathrm{~cm}{ }^{-2}$.

is less than $20 \%$. To our knowledge, most of the state-of-art Pt-free catalysts significantly degrade within $100 \mathrm{~h}$ under the real fuel cell conditions; ${ }^{14}$ therefore, it can be concluded that the carbon based catalysts prepared by the multi-step pyrolysis have extremely good durability as Pt-free catalysts. It can be presumed that there are two main reasons for the extremely high durability of this catalyst: (a) the catalyst is well tolerant against corrosion under the electrochemical conditions because the materials have been well carbonized due to the multi-step pyrolysis, and (b) this material can retain the catalytic activity even if some degree of corrosion occurs on the material surface because active sites exist both in the bulk and on the surface of the carbon.

\section{Conclusions}

Pt-free cathode catalysts for polymer electrolyte membrane fuel cells have been developed by multi-step pyrolysis of FePc and PhRs. The best catalyst in this study, 1000-III- $-\mathrm{NH}_{3}-\mathrm{g}$, shows a quite promising fuel cell performance: $1.0 \mathrm{~A} \mathrm{~cm}^{-2}$ at $0.38 \mathrm{~V}$ with $0.2 \mathrm{MPa}$ of $\mathrm{H}_{2}$ and $\mathrm{O}_{2}$ at $80^{\circ} \mathrm{C}$. It should be noted that the durability tests over $800 \mathrm{~h}$ have been completed and the catalyst showed an extremely good durability as a Pt-free catalyst. It can be concluded that multi-step pyrolysis is a quite effective protocol to convert polymer based precursors into highly active and highly durable ORR catalysts. Further studies require to be done to improve the fuel cell performance and to clarify the reaction mechanism.

\section{Acknowledgements}

This study was financially supported by the New Energy and Industrial Technology Development Organization (NEDO). The EPMA and TEM measurements were carried out in the Center for Advanced Materials Analysis at the Tokyo Institute of Technology.

\section{Notes and references}

1 R. Jasinski, Nature, 1964, 201, 1212.

2 H. Jahnke, M. Schönborn and G. Zimmermann, Top. Curr. Chem., 1976, 61, 133.

3 G. Faubert, G. Lalande, R. Cote, D. Guay, J. P. Dodelet, L. T. Weng, P. Bertrand and G. Denes, Electrochim. Acta, 1996, 41, 1689; G. Lalande, G. Faubert, R. Cote, D. Guay, J. P. Dodelet, L. T. Weng and P. Bertrand, J. Power Sources, 1996, 61, 227; M. Lefevre, J. P. Dodelet and P. Bertrand, J. Phys. Chem. B, 2002, 106, 8705.

4 J. A. R. van Veen, H. A. Colijn and J. F. van Baar, Electrochim. Acta, 1988, 33, 801.

5 H. Schulenburg, S. Stankov, V. Schunemann, J. Radnik, I. Dorbandt, S. Fiechter, P. Bogdanoff and H. Tributsch, J. Phys. Chem. B, 2003, 107, 9034.

6 S. Maldonado and K. J. Stevenson, J. Phys. Chem. B, 2004, 108, 11375.

7 A. Widelov, Electrochim. Acta, 1993, 38, 2493.

8 V. Nallathambi, J. W. Lee, S. P. Kumaraguru, G. Wu and B. N. Popov, J. Power Sources, 2008, 183, 34.

9 G. Wu, K. L. More, C. M. Johnston and P. Zelenay, Science, 2011, 332, 443.

10 M. Bron, J. Radnik, M. Fieber-Erdmann, P. Bogdanoff and S. Fiechter, J. Electroanal. Chem., 2002, 535, 113.

11 R. Z. Yang, K. Stevens, A. Bonakdarpour and J. R. Dahn, J. Electrochem. Soc., 2007, 154, B893.

12 M. Lefevre, E. Proietti, F. Jaouen and J. P. Dodelet, Science, 2009, 324, 71.

13 P. H. Matter, L. Zhang and U. S. Ozkan, J. Catal., 2006, 239, 83; P. H. Matter, E. Wang, M. Arias, E. J. Biddinger and U. S. Ozkan, J. Mol. Catal. A: Chem., 2007, 264, 73.

14 E. Proietti, F. Jaouen, M. Lefevre, N. Larouche, J. Tian, J. Herranz and J. P. Dodelet, Nat. Commun., 2011, 2, 416.

15 E. Yeager, Electrochim. Acta, 1984, 29, 1527.

16 T. Ikeda, M. Boero, S. F. Huang, K. Terakura, M. Oshima and J. Ozaki, J. Phys. Chem. C, 2008, 112, 14706.

17 S. F. Huang, K. Terakura, T. Ozaki, T. Ikeda, M. Boero, M. Oshima, J. Ozaki and S. Miyata, Phys. Rev. B: Condens. Matter Mater. Phys., 2009, 80, 235410.

18 H. Niwa, M. Saito, M. Kobayashi, Y. Harada, M. Oshima, S. Moriya, K. Matsubayashi, Y. Nabae, S. Kuroki, T. Ikeda, 
K. Terakura, J. Ozaki and S. Miyata, J. Power Sources, 2013, 223, 30 .

19 C. W. Chang, Y. Nabae, S. Kuroki, T. Hayakawa, M. Kakimoto and S. Miyata, Chem. Lett., 2012, 41, 923.

20 Y. Nabae, M. Malon, S. M. Lyth, S. Moriya, K. Matsubayashi, N. Islam, S. Kuroki, M. aki Kakimoto, J. Ozaki and S. Miyata, ECS Trans., 2009, 25, 463.

21 M. Chokai, M. Taniguchi, S. Moriya, K. Matsubayashi, T. Shinoda, Y. Nabae, S. Kuroki, T. Hayakawa, M. Kakimoto, J. Ozaki and S. Miyata, J. Power Sources, 2010, 195, 5947; M. Chokai, M. Taniguchi, S. Moriya, K. Matsubayashi, T. Shinoda, Y. Nabae, S. Kuroki, T. Hayakawa, M. Kakimoto, J. Ozaki and S. Miyata, J. Photopolym. Sci. Technol., 2010, 23, 459; M. Chokai, Y. Nabae, S. Kuroki, T. Hayakawa,
M. Kakimoto and S. Miyata, J. Photopolym. Sci. Technol., 2011, 24, 241.

22 E. Desimoni, G. I. Casella, A. Morone and A. M. Salvi, Surf. Interface Anal., 1990, 15, 627.

23 J. Ozaki, K. Nozawa and A. Oya, Chem. Lett., 1998, 27, 573.

24 E. Raymundo-Pinero, D. Cazorla-Amoros, A. Linares-Solano, J. Find, U. Wild and R. Schlogl, Carbon, 2002, 40, 597.

25 N. P. Subramanian, X. G. Li, V. Nallathambi, S. P. Kumaraguru, H. Colon-Mercado, G. Wu, J. W. Lee and B. N. Popov, J. Power Sources, 2009, 188, 38.

26 S. Takenaka, M. Serizawa and K. Otsuka, J. Catal., 2004, 222, 520 .

27 J. Ozaki, S. Tanifuji, A. Furuichi and K. Yabutsuka, Electrochim. Acta, 2010, 55, 1864. 